\title{
The Challenge Of Creating And Maintaining Respected Country-Of-Origin Assets: The Irish Linen Story
}

Kathleen Curtis-Wilson, (E-mail: Kcwil2@mindspring.com), University of Ulster

Gary McCain, (E-mail: gmccain@boisestate.edu), Boise State University

Nina M. Ray, (E-mail: nray@boisestate.edu), Boise State University

\section{IRELAND'S COUNTRY IMAGE}

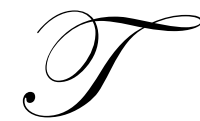

he idea that country images and brand images can be strongly linked is well accepted in international marketing (Paswan et al, 2003; Al-Sulaiti and Baker, 1998; Li and Murray, 2000; Zhang, 1997). A country image projected to the rest of the world is very complex (O'Shaughnessy and O'Shaughnessy, 2000; Insch and McBride, 2002) and multidimensional (Papadopoulos and Heslop, 2002). Some products and their countries are linked so strongly that the brand images include their country of origin (COO). Certain Irish products have such a linkage. A Chicago Tribune article observes that when tourists go to Ireland they often are unable to resist buying fine handmade products that are known worldwide for their quality, such as Aran sweaters, Irish linen and lace, tweeds, Waterford crystal, Belleek china, and Celtic motif jewelry and pewter (Merin, 1991). Of those fine products, linen is inseparably linked with the nation as Irish linen. Irish linen is now a brand name that yields the benefits and problems inherent with brand status and subject to the influences of country of image effects.

\section{COUNTRY OF ORIGIN AND 'BEST LINKS'}

There is a substantial body of literature on the country of origin effect. Papadopoulos and Heslop (2002) state that there are over 766 works in the literature. Initially the research focused on advantages derived when there was a positive COO associated with a product category (Bilkey and Ness, 1982), especially for the classic 'made in' studies, such as those by Nagashima (1970 and 1977). This led to research as to how to create a favorable COO or correct an unfavorable COO (Johansson et al, 1994). This was followed by research into the impact of COO on consumer behavior, specifically the effect of COO stereotypes on consumer beliefs and evaluation of products (Janda and Rao, 1997). O'Shaughnessy and O'Shaughnessy (2000) state that buying based on a country's image is affect-driven, in contrast to buying on the basis of "reputational capital" which is belief-driven.

Recently research on the topic has reflected the complexities of globalization (Phau and Prendergast, 1999). In the global environment, 'made in' increasingly does not mean what is implied and COO is indicated by phrases such as 'assembled in,' 'designed in,' packed in' or 'engineered in.' Insch and McBride (2002) found that country of manufacture exhibited the strongest influence. And, of course, all of these phrases could be completely at odds with the legalities of the 'made in' wording (Jaffe and Nebenzahl, 2001a). With the increase in the number of global firms, although products are produced in many locations, they are being promoted as associated with that country whose $\mathrm{COO}$ is perceived to be strongest.

According to Cateora and Graham (2002, p. 369), Country of Origin effect is "any influence that the country of manufacture, assembly, or design has on a consumer's positive or negative perception of a product." English tea, French perfume, Italian leather, and Irish linen are classic examples "best" linkages. A "best link" is product specific and may not extend to other categories of products from that country. And, country-of-origin effects may vary around the world (Insch and McBride, 2002). 
However, recent issues have surfaced, such as national branding (e.g., "Scotland the Brand," "New Zealand Way" national brand [Jaffe and Nebenzahl, 2001b] and perhaps the first, "Australia: the Brand" [Selling Australia: the Brand, 2002]) and boycotts during terrorism and wartime (Fowler and White, 2003). At a macro level, COO can become an important element in national competitive advantage and governments often undertake trade promotion activities overseas to create a positive $\mathrm{COO}$ association, such as the recent "Cool Britannia" campaign. Stewart-Allen (2002) reports that the British Brands Group has found that this heritage can make a difference in global markets.

And, of course, related is the subject of "geographic indicators," or what the French call appellations d'origine, exemplified by European negotiators at the WTO negotiating to protect food names associated with specific regions, such as the Parmesan cheese, Parma ham, Cheddar cheese, Idaho potatoes, and Swiss chocolates (J. Hughes, 2003; Miller, 2003). Perhaps the discussion of Irish linen is relevant as a geographic indicator and a best link.

While discussing COO, Insch and McBride (2002) suggested that fashion products may vary between societies. Research on another clothing item, the Scottish tartan (Petty, 2004), stesses the need for tartan manufacturers to maintain the Scottish link in order to prove distinctiveness in the minds of consumers. The concern for historical authenticity is alive "as all things Scottish continue to grow in popularity" (Newsome, 2003, p. 23). Therefore, there is global precedent for establishing and protecting COO perceptions of clothing.

\section{IRISH IMAGES}

Demirdjian (2002) reports on Irish Americans and the "consumer awakening to the Celtic culture" (p. 138). He suggests that businesses "re-green" the "Shamrock market" along with the cafes, pubs, restaurants, travel agencies, and better serve this cultural subsegment of the U.S. market. After all, "The Emerald Isle in In" (Burns, 1996, p. 12). In the academic world, the first-ever case (Ryanair) from an Irish author and business school (University College, Dublin) was the overall winner of the European Case Awards (ECCH/Business Week European Case Awards, 2004).

In preparation for a recent St. Patrick's Day, the Wall Street Journal called on "experts of Irish heritage" to help judge the best sources of Aran sweaters (R. Hughes, 2003) but reminded readers that "if you thought St. Patrick's Day festivals were as ancient as the Blarney Stone itself, think again. Today's iconic parades and green beers aren't so much a product of the Emerald Isle, but in fact were born of an Irish diaspora clamoring for respect" (Kinnersley, 2003, p. D2). This interest in Celtic culture leads to a desire to participate in Irish related experiences such as visiting Ireland itself and buying Irish products. Descendants of Irish ancestry often take great pride in their cultural heritage. The Irish diaspora is important since Hsieh (2004) found that country of origin influence differs between "in-groups" and "out-groups." When developing strategy, exporters (in this case, the Irish) should especially promote a product's $\mathrm{COO}$ when introducing to "in-group" foreign markets, such as in the U.S. They will also want to be wary of hazards they may encounter in foreign markets that have confused artificial and authentic Irish images.

The interest in Celtic culture and the inclination to buy to reinforce that interest do not guarantee that Irish culture is, in fact, what is being purchased. Even in the 1970s, Russell (1976) titled one of his essays, "The Wearing Out of the Green," and lamented how American "Irishness is much diluted" (p. 463). He complained about the silly, but harmless, "Kiss Me - I'm Irish" buttons often worn in parades. Recently, Fletcher and Bell (2002) condemned the corruption of true Irish experiences, specifically in the case of the expansion of the Irish pub phenomena without maintaining the true nature of the Irish pub. They assert that it is time to "take the sham out of shamrock" (p. 15) and they label the use of a localized adaptation of foreign cultural symbols as "Hijacking Country of Origin Image." Since many citizens of the world have known about authentic Irish linen for centuries, perhaps the association of linen with Ireland is one way to "unhijack" Ireland's image.

Other examples of conflicting marketing images involve the proud heritage of the island's craftsmen and hard workers (Aran sweaters, Belleek pottery, Waterford crystal, Irish peat for heating homes, and especially linen) with the cultural 'sham' of porcelain leprechauns, "kiss me, I'm Irish" signs, and the ever-present shamrocks on every item of clothing. Even worse, for a recent Christmas season, one could buy from the Creative Irish Gifts Christmas catalog "O'Rudolph the Green Nose reindeer" consisting of a "shamrock and antler-adorned hat, complete with flashing green bulb nose, green twinkling antler lights, and dangling figurines, balls and bells." At issue is whether 
the $\mathrm{COO}$ of Ireland overseas is accurate, whether consumers care about the authenticity of Ireland's product offerings and whether any hijacking of Ireland's $\mathrm{COO}$ for commercial purposes really matters. Of course, many take Brown's (2003, p. 16) view that "authentic authenticity, so to speak, is unattainable" and not care. However, the Irish linen industry does care, as the authors demonstrate later in this paper.

Americans are sometimes surprised to learn, Michael Flatley of Riverdance fame is not Irish, but an American born and raised in Chicago, and that the show itself is faux Irish and a classic example of hijacking country of origin image. The above however does not explain the whole phenomenon as there is also a COO effect at work, even if it is faux. According to Brown and Patterson (2000, p. 656),

the typical Irish theme pub with its green garish décor, pseudo-Gaelic invocations, 'thousand welcomes' doormats, shamrock inspired fittings, peat burning fireplace, freshly brewed stout, wide range of whiskeys, conspiratorial hints of under-the-counter poteen, and general air of pseudo-hiberno bonhomie, cannot be considered indicative of today's Ireland, yesterday's Ireland or any other Ireland this side of The Quiet Man.

Two dangers arise from these faux cues. In the first place, the strength of the illusion creates an image that is in conflict with the real Irish pub and with the real Ireland. Secondly, the illusion of reality is often less (or more) attractive than the actual authentic offering.

In a recent study of Ireland Country Image studies (Ray and McCain, 2003), respondents were asked to respond to a country-of-origin measure (Martin and Eroglu, 1993) for the Republic. Country of origin perceptions (semantic differential 14-item measure, 1 to 7 scale; coefficient alpha of .90) that stand out are that they believe that Ireland is very economically developed, very much represents a free market system, with a strong industrialized democratic and civilian government, and has high literacy rates. Also reported were responses to an open-ended question regarding perceptions of their overall image of Ireland and any thoughts they may have regarding products which are made in Ireland (whether they had ever been to Ireland or not). They said that it is "a very green place," "surprisingly economically developed," "moderate to cold and foggy climate," "historic and has great beer" ("lots of Guinness") 1 , "wool," "lovely people," "great place for Americans to conduct business," "music, dance, and culture in general," and the fact that it offers a "rural-style vacation." Most could not think of any products made in Ireland. One added, though, that s(he) knew that they were "well made." Comments also include "Irish linen is the best" and this person also knows about the "china and crystal." No determination was made regarding the degree to which these are based on accurate perceptions of Ireland or are artifacts of commercialized image creation. Irish linen may be in a better position than other Irish products, however. It has always held a quality reputation and needs no Quiet Man to indicate today's Ireland.

\section{LINEN'S LUSTER}

Hsieh (2004) listed length of time a brand has been in the market as one aspect affecting consumers' familiarity and acceptance. Since Linen cloth, both the making and wearing of it deeply and profoundly affected life in Ireland for three centuries (particularly in the Province of Ulster), a discussion of its history is relevant here. Linen helped to create for the global community a perception of the people and culture on the island of Ireland. During the last 100 years a worldwide audience has associated the words Irish Linen with the country of Ireland along with the famine, leprechauns, Guinness, or green hills and stonewalls. And in the 21st century, Irish linen continues to symbolize quality craftsmanship inspiring confidence in today's discriminating buyer (Irish Linen Guild, 2004). Brown, Hirschman and Maclaran (2001) regret that retro-marketing has been the domain of those marketers trying to capture the "nostalgic inclinations of aging baby-boomers" (p. 183) and discuss the need to expand research "to a wider range of retro-marketing phenomena" (p. 183). Perhaps exploring the lengthy history of Irish linen (and the degree that consumers care about that distinguished history) will provide insight into the challenge of creating and maintaining respected country-of-origin assets and whether the call to associate with the past is relevant.

\footnotetext{
${ }^{1}$ This response is not surprising since The Guinness Storehouse (the number one "fee-paying" visitor attraction in Ireland) aims to

"evoke in visitors an affinity with the brand, since most are not Irish nationals" (Parmar 2003, p. 6).
} 


\section{Irish Linen Throughout the Centuries}

How and why did the small island of Ireland become so identified with linen making that this plain white cloth is as much a part of Irish emigration as its people in creating a global country of origin perception of Ireland? In this paper, the authors explore the importance of linen-making on the island of Ireland ${ }^{2}$ during the past three centuries and discuss the international marketing initiatives that contributed to its global recognition and appreciation of a cloth beautiful enough to be worn by Kings and Queens and durable enough to use as feed sacks and airplane wings. The brand name "Irish linen" was a political decision by the industry itself at the beginning of the last century (Irish Linen Guild, 2004).

Relatively few people are aware of the fiber content of the clothes they wear (in the case of William Bloat the sheets they sleep on) or how those fibers are actually made into cloth. Is your sweater knitted, crocheted, woven - are the fibers fused together? Was your jacket hand-made, hand-loomed or mass-produced in a factory? What is the fabric you wear linen, cotton, wool, silk, lycra, acetate, tensile, a blend? Does everyone reading this know that linen cloth is made from the flax plant? And, that flax is also used to make linseed oil and linoleum? Other notable facts about Irish linen include:

- $\quad$ Emperor Charlemagne only wore linen underwear when his contemporaries favored silk (Irish Textile Journal, 1935).

- $\quad$ Mary Queen of Scots was an avid collector of Irish linen handkerchiefs (Irish Textile Journal, 1935).

- Jackie Kennedy wore a pleated linen dress by Irish designer Sybil Connolly for her formal White House portrait in 1970 (McCrum, 1996).

- Hollywood actress Julia Roberts asked everyone to wear white linen to her 2002 wedding to Danny Moder (Pretty Woman Weds Again, 2002).

- A tea towel, which is part of a series of products designed specifically for The National Trust for Scotland, is decorated with a Scottish national symbol - the thistle. The tag attached to it reads, "Made in Ireland" of "100\% pure Irish linen" (personal purchase by author).

Linen is one of the oldest textiles in the world and the cloth is woven from fiber inside the flax plant. The plant is an annual, so new seeds must be planted every year. Fine linen cloth has been associated with cleanliness, purity and high social status since the days of the Pharaohs. Greeks and Romans manufactured sails and ropes out of linen fiber and traded the cloth for desirable minerals. Ceremonial use of linen expanded with Christianity when the liturgy specified the use of pure linen for altar cloths. Abbeys frequently took the raw flax or linen cloth in trade from tenants for rent payment. (Collins, 1994)

The first recorded use of linen cloth in Ireland occurred in legends from the 8th and 9th centuries referring to warriors and others of noble rank wearing linen tunics (Collins, 1994). By the 11th century, flax was cultivated in Ireland for home use and by the following century ecclesiastical linen made from Irish yarn was used in Winchester Cathedral in England. By the second half of the 17th century, Ireland was aware of the potential market for linen cloth and Ireland's greatest industry - the linen industry - was born.

Men of vision such as the Earl of Strafford (1593-1641) and the Duke of Ormonde (1610-1688) sought to produce better linen cloth with the use of new styles of spinning wheels and looms imported from Holland (Collins, 1994). By the 2nd half of the 17th century, landlords in Ulster offered long leases and low rents to tenants who took up linen manufacturing. Market towns of Lisburn and Lurgan were settled to provide places for selling the cloth, and an improved flax seed was imported from Belgium in 1667. (Ireland did not produce enough seed.) By the end of the century, at least 500 hand looms in Ireland were manufacturing cloth fine enough to compete with the high standard of French linen (Collins, 1994).

\footnotetext{
${ }^{2}$ Throughout this paper, the names Ireland, Northern Ireland, Irish, UK, the province of Ulster are sometimes used without clear distinction. The authors are aware of the modern-day political entities, but try to avoid any political discussion of these entities here.
} 
Techniques in spinning, weaving, and bleaching were greatly improved with the arrival of French Huguenot refugees, particularly Louis Crommelin in 1698. Between the twenty short years of 1685 and 1705, exported linen cloth increased from 92,000 yards to over a half a million yards. By 1780, linen was the dominant industry in Ireland and permeated the rest of cultural life (Collins, 1994).

Until the industrial revolution, linen making was a cottage industry. People shared their lives intimately in their small living spaces with looms and reels, raw flax, and thread; if they were indoors, there was nowhere, morning or evening, where they could get away from the "noisy loom" or the "whirring wheel."

Every aspect of flax growing, processing, and selling the woven cloth was highly regulated by the Trustees of the Linen and Hempen Manufacturers of Ireland, known as the linen board - and detailed records of their meetings \& correspondence were published. Based in Dublin, this body of men settled disputes between growers, determined who benefited from Premiums (subsidies), and made economic policy for each province. Inspectors traveled through the four provinces of Ulster, Leinster, Munster, and Connaught and reported their findings to the Trustees, even though Irish Linen was produced mostly in the historical Province of Ulster (Linens, 1818).

Most of the complaints farmers, manufacturers, and buyers have today are the same as those echoed in the Trustee correspondence. These records enable us to see an industry develop, expand with new technology, falter with a poor harvest, compete with rival manufacturers, self regulate, fight tax reform or propose it, and look to the global community for sales and recognition.

In 1815 - 91,444 acres of flax seed were sown in Ulster. By 1818 in Co. Armagh alone of the 1500 acres sown in flax $-36.5 \%$ with American seed, 32\% from the Baltic countries, 38\% from Holland, slightly more than $2 / 10^{\text {th }}$ of 1 percent British and only $.0007 \%$ were "home-saved" (Flax Crops, 1818). It was noted that the quality and quantity of the flax was much superior to the previous year. So, even hundreds of years ago, the "made in" phrase was ambiguous when applied to Irish linen; perhaps the cloth was made in Ireland, but with imported seed. The country of origin value came from the labor of the Irish farmer and textile workers.

The Trustees held competitions with financial rewards to the winner, encouraging linen manufacturers across the UK to improve their product and promote industry growth. In 1821, £20 was given to the one who made the best 8 pieces of sheeting, made from mill-spun yarn; to be both in color and fabric an imitation of the sheeting made in Russia (Linens, 1818).

There were also premiums given in local counties. In 1816 Linen Inspector Robert Fowler suggested the following for County Down. "I would recommend that a loom, with reed, gears, temples, and shuttle, be given to the person (male or female) who shall have woven the greatest quantity, and of the best quality of linen of and under the set of Eight Hundreds." (Suggestions, 1816, p. 14)

Linen was a valuable product and theft was a constant source of worry. Twenty-four hours a day guards stood at each corner of the bleaching greens to protect the cloth from theft. In 1820 an iron railing was installed along the top of the walls of the Linen Hall marketplace in Coleraine, County Antrim after the second time thieves hid in the gallery until nightfall, then threw the cloth over the wall to their accomplices waiting below (King, 1821).

For most of its history as a clothing fabric, linen has been used primarily for underwear and shirts, but in the second 2nd half of the 20th century the situation reversed, and linen was used less in underwear and more often in fashionable garments. Linen's strength when wet meant that it could be washed repeatedly and effectively so it was always an indicator of status, high standards and hygiene. The fresh, starched, pristine white linen shirt, seen at the neck and wrists became a distinctive sign of a gentleman for all of the 19th and much of the 20th centuries.

Although linen's washability gave it a huge advantage over wools and silks, the effort needed to keep it white made it very 'high maintenance'. Soaking, soaping, washing, bleaching, rinsing, drying, starching and ironing meant that washday in middle-class and working class homes became a nightmare experience. The idea was that washday 
could come round less often the more linen a household owned, and so the infrequency of washday in itself became a form of status symbol.

During the 19th century, Belfast became the headquarters for the majority of linen firms who shared technical and commercial expertise as they gained power and influence in a worldwide marketplace. Belfast became known as Linenopolis, demonstrating its international reputation (Boyle, 1988). The Civil War in the United States substantially reduced its production of cotton cloth, enabling Belfast to expand its linen production as an acceptable substitute. Between 1860 when the Civil War started and 1875, the number of steam powered looms increased from fewer than 60 to 17,000 with a workforce of over 43,000. Belfast doubled in size between 1841 and 1871, and doubled again by 1901 when over 70,000 people in Ulster were employed in the linen industry (Carter, 1952).

In the year 1903 enough linen was woven in Ireland to wrap a six-foot wide strip around the earth at the equator. The industrial revolution brought increased production capabilities and an ever-growing demand for workers. From 1891-1926, a full 35 years - one in every three workingwomen in Belfast was directly employed in the textile industry (Robinson \& Cleaver, 1910).

The "best link" of Ireland and linen has historic $20^{\text {th }}$ century importance too. Linen connected the tiny island of Ireland to the world in ways not previously appreciated. On the eve of the First World War, Ulster had become the largest linen-producing region in the world but ports in the North of Europe were hostile or shut by the French government. Retaliatory measures imposed by the English forced Irish linen merchants to look for new markets and new strategies for reaching them. Irish linen was a desirable commodity in the climates of South American and Australia and salesmen continued to expand their territories to meet the demand of buyers - and sell the quantity of linen being produced.

Elegant luxury liners were outfitted with enough linen cloth to keep workers employed for years, and passengers wore linen cloth from chemises that hugged the skin to parasols that protected against the sun. The great Titanic commissioned 40,000 Ulster linen damask napkins to use on her maiden voyage from the firm of Ewart Liddell Ltd. in Co. Armagh (Irish Linen, 1957).

As late as 1950 the firm had sales representatives marketing Irish linen in 66 separate countries and investment capital of more than $£ 1,000,000$ (Irish Linen, 1957, pp. 12-13). The fabric signified the craftsmanship of Ireland and the word "linen" had become inseparable from Ireland and its people.

Gifts to state governments at official functions and the use of highly publicized events or famous individuals to promote Irish Linen kept the public aware of the brand name Irish Linen from decade to decade. It is one of the most successful publicity campaigns that extended for more than a hundred years. For example:

- $\quad$ The Northern Ireland Prime Minister Captain Terrence O'Neill presented two Ulster linen banquet size tablecloths to President Johnson at the White House on St. Patrick's Day in 1964 (Linen for the President, 1964).

- $\quad$ The Beatles (an English rock group) also meant financial rewards and notoriety for the Ulster Linen industry. When millions of fans across the globe wanted to wear the same style of boot as the Beatles - Ulster thread makers saw a demand for their thread escalate dramatically. The Ulster Weaving Co. contracted with the Beatles to incorporate their faces into an exclusive linen tea towel that was sold internationally.

- $\quad$ Short Bros. \& Harland negotiated with a Belfast linen concern to develop a foam-backed seat covered with durable linen for use on their commercial airlines, so that air travelers would ride on "Irish Linen" (Linen Covering for Aircraft Sales, 1964).

Over the centuries, Irish linen was used to line the inside of shoes, cover airplane wings, hold feed and seed for farmers, to make maps, fire hose, flags and banners, for architectural drawings, and to cover the body of the rich and poor from swaddling at birth to the death shroud. 


\section{Continuous Innovations}

Just as the Civil War cotton shortages provided a strategic advantage for linen producers, modern innovation of synthetic materials provides a competitive challenge. Every product has to continuously protect its brand position and confront competition through innovation.

Over the decades Irish linen manufacturers identified their strengths in order to find a particular niche in a changing marketplace. In the $19^{\text {th }}$ century three linen fabrics - cambric, lawn, and damask - used very finely spun yarn to achieve the high quality demanded by the consumer. Hand spinners in Lisburn, Lurgan, Banbridge and Dromore reached new levels of achievement to spin exceptionally fine yarn at a time when coarser mill-spun yarns were forcing many hand spinners out of the industry. But hand spinners could not produce the quantity needed to increase the production of this highly saleable cloth. With the adoption of wed-spinning, a process invented by James Kay in 1825 , finely spun yarn could finally be factory spun. George Benson of Belfast designed a sewing machine for hemstitching handkerchiefs in 1879 and within twelve years he had sold eight thousand, giving employment to as many as three women per machine (Crawford, 1987).

During the second half of the $19^{\text {th }}$ century linen manufacturers displayed their products at international industrial exhibitions in London, Dublin, Paris, Vienna, Philadelphia and Chicago. The success of the industry at these widely attended events was exploited in trade journals, newspapers and by manufacturers' self-promotion initiatives. By the early $20^{\text {th }}$ century there was a very strong shirt collar industry in Northern Ireland. Since white-collar workers worldwide might replace their detachable collar several times a day, the demand for collars was astounding. By 1912 Londonderry alone exported twenty million collars annually (Crawford, 1987).

Each time a piece of equipment was improved or new technology invented, the textile industry became more committed to manufacturing linen as their staple textile. The success and failure of the industry depended on fickle worldwide women's fashion demands and the fluctuating price of flax seed imported into Ireland each season.

By the $20^{\text {th }}$ century most textile manufacturing was located in Northern Ireland and foreign political situations brought about new challenges for the industry. When the United States would no longer purchase Irish linen embroidered in China after the Communist Revolution in 1949, sales of linen to Hong Kong plummeted. The 1958 revolution in Cuba wiped out 13\% of the market for plain bleached linen. The Brazilian linen market also disappeared and new competition from Poland and Czechoslovakia had to be faced, but it was the rise of cheap cotton imports from India and Hong Kong after 1954 that caused a huge problem for textile manufacturers across Northern Ireland (Crawford, 1987).

Changes in fashion, the promotion of ready-to-wear shirts, and the onset of "the troubles" in the 1920s predicted an ultimate decline in the Derry custom shirt industry. Derry again gained prominence in 1948 when Courtaulds set up the first plant in Northern Ireland to manufacture man-made fibers, followed in the 1950s and 1960s by companies such as Du Pont and Monsanto from the United States, and others from Britain, Holland and West Germany. It was hoped that this influx of new manufacturing capabilities would replace the outdated and declining shirt industry. By the end of the 1960s, "the troubles" once again changed the lives and expectations of thousands of workers in Derry and throughout Ulster. With another downturn in the textile industry, international manufacturers were unwilling to build factories or invest capital in such an unstable environment.

Even though the second half of the $20^{\text {th }}$ century was a period where new technology in the spinning, weaving and finishing of linen was developed, the industry knew it must pay closer attention to marketing and research blending man-made fibers with linen to continue to compete globally. Throughout the world great changes were happening in textile manufacturing. The public now wanted more color and better design with immediate availability and at a cheap price point. When paper handkerchiefs, napkins, placemats, and hand towels were introduced into the market many companies unable to retaliate were forced out of business. Only the companies willing and able to diversify into the production of fine (expensive) apparel goods to supplement the declining international market for household goods survived. 
Since the early 1980s Italian designers have chosen the fine quality of Irish linen for fashionable apparel. Designers such as Dublin born Paul Costello, German Anne Demeulemeester and Dai Rees from the coast of South Wales have brought new attention to Irish linen. These designs, presented at fashion shows in Paris, London and Milan, have given consumers a renewed appreciation for this brand name that has stood for quality for so many decades.

For women living across the world - especially in the United States, South America, Europe and the UK, Irish Linen is still a name that evokes thoughts of a summer day, a cool breathable fabric of fine quality - a texture that is smooth and lightweight against the skin.

Of course there is the issue of wrinkles, one accepts them or hates them. Wrinkles or not, Irish linen is still recognized as the finest linen in the world (Webster, 1990).

By the year 2004, woven fabric has changed dramatically from its properties of earlier centuries. Inventions in science and technology have created woven fabrics that were unimaginable only a few decades ago. Agrotextiles, geotextiles, conveyor belts, cinema screens, filtering fabrics, wire mesh for outdoor fence and furniture are all part of the textile industry today and still woven on a loom - though one would not recognize it as the same piece of equipment used to make a heirloom damask tablecloth. Today natural fibers of silk, cotton, wool, and linen are blended together in various combinations to make new exciting fabrics for fashionable clothing and home decoration.

Frequently, natural fibers are blended with manmade fibers such as Irish Linen plus Lycra ${ }^{\circledR}$ a fabric developed by Professor Brian Hill, formerly chairman of textile technology at the University of Ulster. This collaboration between Ulster Weavers and William Ross yarns, the NI government, University of Ulster, and Du Pont, allowed for the creation of this innovative fabric that was presented at the Paris Fashion Show in 2001. Irish Linen plus Lycra was launched in Paris in February 2002 at a salon show held in the UK embassy in Paris during Premiere Vision. It has the lovely properties of linen without the wrinkles and helps the fabric retain its "newness retention" for years (Chase, 2003).

Today fine quality linen is still manufactured in Ireland, primarily in Ulster, but the textile industry is now a much smaller portion of the overall economy in N. Ireland. New ways to blend textiles for fashionable clothing, fabrics and stunning technical advances keep the industry vital.

In the $21^{\text {st }}$ century the following three companies demonstrate linen's continued importance to Northern Ireland. Ulster Weavers manufactures an extensive range of Irish linen apparel and furnishing fabrics and received World Class Manufacturing Status in 2003, the first textiles company to ever be awarded this standard. John England is a small firm known for their excellent fashion designs and use of linen blended fabrics such as wool and linen or cotton and linen. Baird McNutt has been extremely successful selling linen cloth to major United States manufacturers such as Bloomingdales, Saks $5^{\text {th }}$ Avenue, and Talbots.

Although Irish linen is manufactured in far smaller quantities than it was a century ago, the brand name has consistently stood for quality and integrity enabling today's buying public to appreciate and acknowledge Irish linen as a desirable wearable fabric much as their ancestors did when there were far fewer choices of fabrics for clothing. It is a brand name that has stood the test of time and continues to represent the island of Ireland to many people worldwide.

The Irish Linen Guild (ILG) is a voluntary promotion organization drawing its membership and funding from all sections of the Irish Linen Industry. In 2004 it consists of 26 companies ranging from spinners and weavers through to finishers, designers and merchants. It acts to maintain high standards within the industry and promote Irish Linen in national and international textile and clothing markets. The Irish Linen logo is recognized as of prime importance it is a registered trademark, which can only be used to mark Irish Linen products manufactured by guild members. The use of the logo is monitored closely by the guild, especially in its most strategic areas of the EU, USA and Canada, Japan, Australia and New Zealand, Taiwan, and Korea. They have the most trouble protecting their trademark from China, and unfortunately, adequate resources for trademark protection are lacking. 
The guild acts to promote the industry as a whole and expand knowledge about its natural properties. The guild vigorously promotes the industry by exhibiting at international textile fairs such as Heimtextil in Frankfurt and Premiere Vision in Paris. The Guild regularly organizes press trips, bringing journalists to Northern Ireland to observe the Irish Linen industry first hand. In-store promotions and joint ventures with top designers also help to raise the profile of Irish Linen. The Guild engages in education of retail sales staff on how linen is made, its advantages as a fiber, and how best to care for linen. It has also published leaflets aimed at consumer care. Education packs are also available for schools (Irish Linen Guild, 2004).

The Guild's promotional activities reflect the progressive nature of the Irish Linen industry. As a result of continuous research, product development, new technology and a commitment to investment, the industry now combines modern innovation with traditional values to improve its competitiveness in an increasingly demanding world market whilst still maintaining the special qualities for which it is renowned. With an estimated turnover of $£ 150$ million and exports of $£ 85$ million, the Irish Linen industry plays an important role in the economy of Northern Ireland and is one of the few textile sectors in the UK, which shows a healthy balance of payments. (Campbell, 2003)

\section{STRATEGIC CHALLENGES OF IRISH LINEN AS A NATIONAL BRAND}

In an informal replication of the Ray and McCain research (2003), one current author asked a U.S. 2004 International Marketing class to respond to the same $\mathrm{COO}$ scale questions about the Republic of Ireland. In addition, students were asked to list at least two products that come to mind when they think of the phrase, "Made in Ireland." Seven of 45 responses listed a textile category (e.g., "clothing," "wool," "sweaters," and "textiles"). These included kilts and tartans, but no one listed Irish Linen. The small size and specificity of the sample group certainly limits the representativeness and generalizability of their response. However the issue of how well the next generation recognizes Irish linen as a premier brand should be a concern to the industry. Other gaps in the image of Irish linen are evident in a Wall Street Journal article about luxury linens that cost as much as $\$ 3,000$ a tablecloth that not only fails to mention Irish linen but refers to employing Vietnamese seamstresses to embroider designs on linens sold in exclusive boutiques in San Francisco (McMullen, 2004). These may be indications of potential concerns for the brand of Irish linen.

The value of a brand is an asset. Strong brand knowledge can lead to fundamental differences in consumer behavior in favor of the brand over competitors and can produce differential responses to specific marketing activities by consumers (Hoeffler and Keller, 2003).

Aaker (1996) provides a set of guidelines for building and managing strong brands. The Irish linen brand identity, value proposition, and position are inseparably connected with the Irish country of origin and quality. Manufacturers, distributors and the trade organizations of both the Republic and Northern Ireland must pay attention to the execution of their communications to provide consistency of messages that maintain their identity and position over time. Changes that deviate should be strongly resisted. They should fiercely enforce systems that ensure that any new manufacturers and distributors conform to the standards the brand represents. The brand should be leveraged through brand extensions to take advantage of its strengths but only if the brand identity will be used and enforced.

Two major components make up the Irish linen brand: the high quality linen cloth and the Irish country of origin. How Ireland is perceived affects Irish linen. How Irish linen is perceived is a component of the Irish image. Brand extensions that involve both Irish linen and Ireland should be considered.

There is more to the Irish linen image than cloth. As described in the evolution of the Irish linen history, the making of Irish linen is a key part of the Irish culture. Tourism is another industry that can use and perhaps expand on the Irish linen brand image. Silberberg (1995) reports an increased importance of culture, especially as exhibited in "museums and heritage sites," as a motivation for travel. Included in their "past-related consumption categories," Chronis and Hampton (2003) include retro-style objects, collectibles, past narratives such as books and movies, historical societies, artifacts, heirlooms, genealogies, heritage events, and heritage sites. Yale (1991) tells us: 
... the fasionable concept of 'heritage tourism' really means nothing more than tourism centred on what we have inherited, which can mean anything from historic buildings, to art works, to beautiful scenery. (p. 21)

Key elements in heritage tourism are nostalgia for times long gone and the artifacts that go with them. Morris Holbrook describes the meaning of nostalgia as referring "to a longing for the past, a yearning for yesterday, or a fondness for possessions and activities associated with the days of yore" (Holbrook, 1993, p. 245). Relatively few young women across Ireland are running looms, cutting cloth or embroidering shirtfronts. But the enormous mill and factory buildings that punctuate the rural landscape and delineate streets and neighborhoods across Ulster are daily reminders of a time when linen thread and fabric were coveted by men and women around the world. Certainly, the above-mentioned fondness for artifacts and activities for the "days of yore" could be applied to the extensive heritage of the linen industry in Ireland. Interestingly, $98 \%$ of tourists to the Republic of Ireland are motivated by the opportunity to visit 'cultural and historic' places. Certainly the Irish Linen Center \& Lisburn Museum falls into the category of cultural tourism, as would heritage museums of old linen mills, etc. As for Northern Ireland, Stanbridge (2001) tells her British compatriots that it is time to explore 'the Celtic connection.' Northern Ireland tourism industry recently celebrated a record year. Visitor numbers were pushing two million and many consider this 12 percent increase remarkable during hard times for tourism with Europe showing no growth in 2003 (Ogle, 2004).

Country image is most often not directly under marketers' control (Papadopoulos and Heslop, 2002). We do not intend to dismiss the reality of some concerns regarding the tourist images of political strife associated with the "troubles" in the North (Bairner and Shirlow, 2003; Murphy, 2003), but we also have found recent studies that show that tourists evaluate the North very well on scenery and places to visit and also on having a safe and secure environment (Lennon, Weber, and Henson, 2001; Ogle, 2004).

We recommend that institutions in Ireland track tourists based on the changing role of cultural/heritage tourists in general and consider if Ireland's linen heritage and image can be used in helping visitors "search for authentic otherness" (MacCannell, 2002, p. 150). Certainly there is nothing so important to heritage tourists as ones own heritage; the "legacy" tourists discussed in McCain and Ray (2003) think so. And, one way that the Irish diaspora find information on their ancestors is through the records and contacts of the flax industry and they might do so by visiting the Linenhall Library in Belfast.

There are numerous opportunities to build on relatively untapped existing heritage sites that already feature Irish linen. Collections that have existing linen displays, such as Castle Ward and Springhill House in the North and Cavan County Museum in the Republic could expand their exhibits and become resources that contribute to creating a stronger brand image. Old mill sites offer heritage opportunities. Sion Mills in County Tyrone has begun to restore mill facilities to attract modern-day visitors, capitalizing on their designation as a conservation area (the village has been officially identified as one of special architectural and historical interest) (A Brief History, 2004). The Village also contains several individual buildings of considerable architectural interest.

\section{CONCLUSIONS}

Throughout this paper, the authors have referred to an aggregate brand of Irish Linen. Austin, Siguaw and Mattila (2003) suggest that marketers "proceed with extreme caution" (p. 77) when "aggregating data within a specific product category." What would be consumers' reactions to a possible "Ireland the Brand," following the lead of "Australia: the Brand," "Scotland the Brand," and "New Zealand Way?" And, should both Irelands consider joining other European nations to protect Irish linen as a "geographic indicator?" We encourage all involved with anything Irish to participate in a conscious effort to build the brand equity of Irish linen by a) strengthening all institutions involved in the production, distribution and promotion of Irish linen, b) protecting the brand identity through aggressive defense of the use of the title of Irish linen wherever it may appear, and c) expanding the domain of Irish linen to include products and services that contribute to the brand identity of quality and Ireland as the country of origin. 


\section{REFERENCES}

1. A Brief History of Sion Mills (2004) Retrieved 20 October, 2004 from http://www.sionmills.co.uk

2. $\quad$ Aaker, David A. (1996) Building Strong Brands, New York: Free Press.

3. Al-Sulaiti, K. I. and M. J. Baker (1998) Country of origin effects: A literature review. Marketing Intelligence and Planning, 16 (3), 150-199.

4. Austin, Jon R., Judy A. Siguaw, and Anna S. Mattila (2003) A re-examination of the generalizability of the Aaker brand personality measurement framework. Journal of Strategic Marketing 11 (June), 77-92.

5. Bairner, Alan and Peter Shirlow (2003) When leisure turns to fear: fear, mobility, and ethno-sectarianism in Belfast. Leisure Studies 22 (July), 203-221.

6. Bilkey, Warren J. and Erik Ness (1982) Country of origin Effects on Product Evaluations. Journal of International Business Studies 13 (Spring), 89-99.

7. Boyle, Emily (1988) Linenopolis: The rise of the textile industry in J C Beckett et al (eds.). Belfast: The making of the city. Belfast, 42-55.

8. Brown, Stephen (2003) Marketing to Generation ${ }^{\circledR}$. Harvard Business Review 81(6), June, 16-17.

9. Brown, Stephen, Elizabeth C. Hirschman, and Pauline Maclaran (2001) Presenting the past: on marketing's re-production orientation. Imagining Marketing: Art, Aesthetics and the Avant-Garde, Stephen Brown and Anthony Patterson, eds., Routledge Interpretive Marketing Research, 145-191.

10. Brown, Stephen and Anthony Patterson (2000) Knick-nack Paddy-whack, Give a Pub a Theme. Journal of Marketing Management 16, 647-662.

11. Burns, Mike (1996) The Emerald Isle in In. Europe (358: July/August), 12-13.

12. Calvert, Raymond (1928) The ballad of William Bloat. In H. R. Carter, Brave Crack: an Anthology of Ulster Wit and Humour (1951). Belfast, Northern Ireland.

13. Campbell, Russell (2003) All Stitched Up. Ulster Business (01 May), Retrieved October 2, 2004 from News and Events http://www.irishlinen.co.uk

14. Carter, William (1952) A short history of the linen trade. Vol II from the industrial revolution to the present time. Belfast: Carter Publications.

15. Cateora, Philip R. and John L. Graham (2002) International Marketing, New York: McGraw-Hill.

16. Chase, Nan (2003) Textiles That Can Take It; Stretchy Leathers for Couches, Carpets That Shed Spills. The Washington Post, (February 6), H.01.

17. Chronis, Athinodoros and Ronald D. Hampton (2003) Byzantine at the Edge of History: Consumption of the Past at a Heritage Exhibition. All Changed, Changed Utterly? European Association for Consumer Research, (June), Dublin, Ireland.

18. Collins, Brenda (1994) Flax to Fabric, The Story of Irish Linen. Northern Ireland: Irish Linen Centre \& Lisburn Museum.

19. Crawford, W. H. (1987) The Irish Linen Industry, County Down, Northern Ireland: Ulster Folk and Transport Museum and Irish Linen Guild, 21-41.

20. Demirdjian, Z.S. (2002) The Irish Americans: A Consumer Awakening to the Celtic Culture. In Enabling Technologies and Marketing Education, Regina P. Schlee and John A. Schibrowsky, eds. Proceedings of the 2002 Marketing Educators' Conference. Madison, Wisconsin: Omnipress, 138-143.

21. ECCH/Business Week European Case Awards 2004 (2004) Eccho: The Newsletter of the European Case Clearing House (Spring), 2.

22. Flax Crops (1818) Proceedings of the Trustees of the Linen and Hempen Manufactures of Ireland. Dublin, Ireland: William Fold and Sons, 69-70.

23. Fletcher, Richard and Jim Bell (2002) Hijacking Country Of Origin Image. The Marketing Landscape: Signposts for the Future, Proceedings of the Annual Conference $2^{\text {nd }}-5^{\text {th }}$ July, UK Academy of Marketing: The Chartered Institute of Marketing.

24. Fowler, Geoffrey A. and Erin White (2003) U.S. Multinationals See Local Ties Tested by Anti-American Tensions. Wall Street Journal (March 24), A12.

25. Hoeffler, Steve and Kevin Lane Keller (2003) The marketing advantage of strong brands. Journal of Brand Management, (August), 421-445.

26. Holbrook, Morris (1993) Nostalgia and Consumption Preferences: Some Emerging Patterns of Consumer Tastes. Journal of Consumer Research 20, 245-256. 
27. Hsieh, Ming-huei (2004) An investigation of country-of-origin effect using correspondence analysis: a cross-national context. International Journal of Market Research 46 (3), 267-295.

28. Hughes, Justin (2003) Surrendering words to the EU. Managing Intellectual Property 129 (May).

29. Hughes, Robert J. (2003) Catalog Critic: Close-Knit and Irish. Wall Street Journal (March 14), W11C.

30. Insch, Gary S. and J. Brad McBride (2002) The impact of country-of-origin cues on consumer perceptions of product quality: A binational test of the decomposed country-of-origin construct. Journal of Business Research 57, 256-265.

31. Irish Linen - an account of its processes of manufacture, incorporating the history of William Ewart and Son Limited (1957). Belfast: William Ewart and Son.

32. Irish Linen Guild (2004) Retrieved 2 October, 2004 from http://www.irishlinen.co.uk

33. Irish Textile Journal (1935) clipping which is part of H9 A S Moore collection Belfast Central Library.

34. Jaffe, Eugene D. and Israel D. Nebenzahl (2001a) Legal Aspects of Country Image. National Image and Competitive Advantage: The Theory and Practice of Country-of-Origin Effect. Herndon, VA: Copenhagen Business School Press, 141-159.

35. _ (2001b) Managing Country Image by Industry and Government. National Image and Competitive Advantage: The Theory and Practice of Country-of-Origin Effect. Herndon, VA: Copenhagen Business School Press, 123-140.

36. Janda, Swinder and C.P. Rao (1997). The Effect of Country-of-Origin Related Stereotypes and Personal Beliefs on Product Evaluation. Psychology and Marketing 14 (7), 689-702.

37. Johansson, Johny K., Ilkka A. Ronkainen, and Michael R. Czinkota (1994) Negative Country of Origin Effects: The case of the New Russia. Journal of International Business Studies 25 (1), 157-176.

38. King, James (1821) Proceedings of the Trustees of the Linen and Hempen Manufactures of Ireland. Dublin, Ireland: William Fold and Sons, 127.

39. Kinnersley, Hannah Kate (2003) Desktop Traveler/St. Patrick's Day. Wall Street Journal (March 11$)$, D2.

40. Lennon, Ron J., Michael Weber, and James Henson (2001) A Test of a Theoretical Model of

41. Consumer Travel Behaviour: German Consumers' Perception of Northern Ireland as a Tourist Destination. Journal of Vacation Marketing 7 (1), 51-62.

42. Li, Z. G. and W. L. Murray (2000) Global sourcing, multiple country-of-origin facets, and consumer reactions. Journal of Business Research 47 (2), 121-144.

43. Linen Covering for Aircraft Seats (1964, April 11). The Linen Trade Circular and New Fibres Review, Belfast: H.K.Carter Publications, 12.

44. Linen for the President. (1964, March 28) The Linen Trade Circular and New Fibres Review, Belfast: H.K.Carter Publications, 8.

45. Linens (1818) Proceedings of the Trustees of the Linen and Hempen Manufactures of Ireland. Dublin, Ireland: William Fold and Sons, Appendix, 84.

46. MacCannell, Dean (2002) The Ego Factor in Tourism. Journal of Consumer Research 29 (1), 146-151.

47. Martin, Ingrid and Sevgin Eroglu (1993) Measuring a Multi-Dimensional Construct: Country Image. Journal of Business Research 28 (3), 191-210.

48. McCain, Gary and Nina M. Ray (2003) Legacy Tourism: The Search for Personal Meaning in Heritage Travel. Tourism Management 24 (6), 713-717.

49. McCrum, Elizabeth (1996) Fabric \& Form, Irish Fashion since 1950. Belfast, Northern Ireland: Sutton Publishing Ltd.

50. McMullen, Troy (2004) Luxury Linens Set the Table. Wall Street Journal, (October 15), W10.

51. Merin, Jennifer (1991) Ireland's bust buys In woolens, linens, lace and spirits, bargains thrive like shamrocks. Chicago Tribune, Final Edition C (March 17), 12.

52. Miller, Scott (2003) Europe Says, 'that Cheese Is No Cheddar!' Wall Street Journal (February 13$)$, B1.

53. Murphy, Helen (2003) Exploring leisure and psychological health and wellbeing: some problematic issues in the case of Northern Ireland. Leisure Studies 22, 37-50.

54. Newsome, Matthew A. C. (2003) Fascinating Facts: Fact or Fiction? The Scottish Banner (October), 23 and 25.

55. Nagashima, A. (1970) A Comparison of Japanese and U.S. Attitudes Toward Foreign Products. Journal of Marketing 34 (January), 68-74. 
56. _ _ _ (1977) A Comparative Made In’ Product Image Survey Among Japanese Businessmen. Journal of Marketing 41 (July), 95-100.

57. Ogle, Brian (2004) Northern Ireland Tourism review, Travel News (June), 20.

58. O'Shaughnessy, John and Nicholas J. O'Shaughnessy (2000) Treating the Nation as a Brand: Some Neglected Issues. Journal of Macromarketing 20 (1), 56-64.

59. Papadopoulos, Nicolas and Louise Heslop (2002) Country Equity and Country Branding: Problems and Prospects. Journal of Brand Management 9 (April), 294-314.

60. Parmar, Arundhati (2003) Guinness intoxicates. Marketing News (November 10), 4 and 6.

61. Paswan, Audhesh K., Shailesh Kulkarni, and Gopala Ganesh (2003) Loyalty towards the country, the state and the service brands. Journal of Brand Management (February), 233-251.

62. Petty, Ross D. (2004) Of Tartans and Trademarks. Proceedings of the European Applied Business Research Conference (paper \#138) Edinburgh, Scotland.

63. Phau, Ian and Gerard Prendergast (1999) Integrating Country of Origin Research: Concepts, Methods and Strategies. Journal of International Marketing and Exporting 4 (2), 71-83.

64. $\quad$ Pretty Woman Weds Again. (2002, July 7). Sunday Life (Belfast), 23.

65. Ray, Nina M. and Gary McCain (2003) Taking the 'Sham' out of Shamrock: Legacy Tourists Seek the 'Real Thing' European Advances in Consumer Research Vol. 6, Darach Turley and Stephen Brown, eds., 54-59.

66. Robinson \& Cleaver (1901) Some Historical Notes on Linen-Ancient and Modern. Belfast, Northern Ireland.

67. Russell, Francis (1976) The Wearing Out of the Green. National Review (April 30), 455+.

68. Selling Australia: the Brand (2002) Princeton, NJ: Films for the Humanities \& Sciences.

69. Silberberg, T. (1995) Cultural Tourism and Business Opportunities for Museums and Heritage Sites. Tourism Management 16(5), 361-365.

70. Stanbridge, Jane (2001) Time to Enjoy the Celtic Connection. Marketing (October 25), 25-26.

71. Stewart-Allen, Allyson L. (2002) Heritage Branding Helps in Global Markets. Marketing News (August 5), 7.

72. Suggestions for granting Local Premiums in the County of Down. (1816) Proceedings of the Trustees of the Linen and Hempen Manufactures of Ireland. Dublin, Ireland: W. Folds and Sons, 14.

73. Webster, Sandra Betzina (1990) If It Wrinkles, It Must Be Linen. San Francisco Chronicle, Final Edition, (May 24), B.4.

74. Yale, P. (1991) From Tourist Attractions to Heritage Tourism, Huntingdon: ELM Publications.

75. Zhang, Y. (1997) Country-of-origin effect: The moderating function of individual difference in information processing. International Marketing Review, Vol. 14, No. 2, 266-287. 


\section{NOTES}

